\title{
In Vivo Trypanocidal activity of Hydroethanolic extract of Hymenocardia acida stem bark in Rats
}

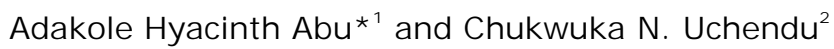 \\ 1. University of Agriculture, Makurdi, nigeria \\ 2. University of Nigeria, Nsukka, Nigeria \\ * Corresponding author email: adakoleabu@yahoo.co.uk
}

\begin{abstract}
The in vivo trypanocidal efficacy of Hydroethanolic extract of Hymenocardia acida stem bark was evaluated in Wistar rats. Three groups of rats were treated orally with the extract at doses of 100,200 and $400 \mathrm{mg} / \mathrm{kg}$ body weight for 6 days. Two other groups received the vehicle and Diminazene accurate at $3.5 \mathrm{mg} / \mathrm{kg}$ to serve as negative and positive control respectively. The mean survival period of infected animals, daily level of parasitaemia, packed cell volume, total and differential leukocyte counts were evaluated. Oral administration of the extract did not significantly $(\mathrm{P}>0.05)$ affect the packed cell volume. However, the extract reduced the level of parasitaemia and prolonged the life span of infected rats. This study shows in vivo potential of hydroethanolic extract of $\mathrm{H}$. acida in the treatment of African trypanosomosis.
\end{abstract}

Key words: Albino rats, Trypanocidal, Hymenocardia acida, Herbal drug, Parasitemia, African Trypanosomiasis.

\section{Introduction}

In developing countries, the use of products of plant origin by persons with limited access to modern medicines to treat human and animal diseases is widespread. Herbalists and herdsmen in North Central Nigeria have claims to the use of medicinal plants in the traditional management of African trypanosomosis (Atawodi et al., 2002; Abu et al., 2009). African trypanosomosis is a complex protozoan disease of man and livestock caused by several species of trypanosomes and transmitted by tse tse fly. Low quality ejaculate, reduced sperm motility and concentration (Akpavie et al., 1987), low foetal weights, premature births, neonatal losses, poor reproductive performance and lactation (Faye et al., 2004) are some of the problems associated with AAT. Despite efforts during most of the last century, the disease has proved difficult to eradicate.

Chemotherapy, the main means of controlling the disease is under threat due to parasite resistance (Maser et al., 2003) and toxicity of the trypanocidal drugs (Amaechi, 2001). The poor prospect for a vaccine due to antigenic variation of the parasite (Nantulya and Moloo, 1989) is further compounded by unwillingness of the pharmaceutical industry to develop new compounds because of uncertain and unprofitable market or perhaps the localized nature of the disease. The few commercial trypanocides have been in use for well over 40 years. Thus, the search for medicinal plants with trypanocidal activities is of research interest (Hoet et al., 2004).

Several reports indicate antitrypanosomal activity exits in some medicinal plants (Ibrahim et al., 2008 and Shuaibu et al., 2008). Also there have been previous reports of in vitro antitrypanosomal efficacy of leaf (Hoet et al., 2004) and root bark (Atindehou et al., 2004) extracts of Hymenocardia acida of Beninese and Ivorian origins respectively. A strong in vitro trypanocidal activity of crude extracts of Hymenocardia acida stem bark was recently reported (Abu et al., 2009). However, there is paucity of information on in vivo trypanocidal efficacy of crude extract of Hymenocardia acida stem bark. The present study was planned with a view to assess in vivo trypanocidal efficacy of hydroethanolic extract of Hymenocardia acida stem bark in Wistar rats.

\section{Material and methods}

Plant material: The stem bark of Hymenocardia acida was collected within the premises of University of Agriculture, Makurdi and authenticated by Mr. Patrick Ekwuno of College of Forestry, University of Agriculture Makurdi, Nigeria. Voucher specimen was deposited at the College herbarium.

Preparation of crude extract: The stem bark was washed, air dried at room temperature for one week, 
Table-1: Phytochemical screening of hydroethanolic extract of $\mathrm{H}$. acida for alkaloids, glycosides, flavonoids, saponins, tannins, terpenoids, anthraquinones and phlobatannins.

\begin{tabular}{lc}
\hline Alkaloids & +++ \\
Anthraquinones & -- \\
Glycosides & ++ \\
Flavonoids & +++ \\
Saponins & +++ \\
Tannins & +++ \\
Phlobatannins & + \\
Terpenoids & + \\
\hline+++ highly present, ++ = moderately present, + = lightly present, -- = absent
\end{tabular}

pulverized and stored in air-tight container until required. One hundred grams of powdered material was soaked in $500 \mathrm{ml}$ of $70 \%$ ethanol and stirred intermittently for 48 hours at room temperature. The material was filtered using sterile cotton wool and Whatman (No.-1) filter paper; the residue was resuspended in the same amount of solvent and then filtered three more times. The pooled filtrates obtained were dried at room temperature under the electric fan. The extracts were stored in air-tight containers at $4^{\circ} \mathrm{C}$ until needed.

Animals: Twenty five white albino rats of weighing $120 \mathrm{~g}-150 \mathrm{~g}$ were obtained from the College of Health Sciences, Benue State University Makurdi, Nigeria. The animals were kept in polypropylene cages under room temperature, with 12-hour light and 12-hour dark cycle and were allowed to acclimatize for two weeks. The animals were provided commercial feed (Grand Cereals and Oil Mills Ltd, Bukuru, Jos, Nigeria) and clean water ad libitum. Protocols for this experiment was in accordance with the guidelines on the care and well being of research animals $(\mathrm{NIH}$,
1985) and was approved by the Departmental Ethics Committee.

Phytochemical screening: Analysis of major phytoconstituents was carried out qualitatively using standard procedures (Odebiyi and Sofowora, 1978).

Trypanocidal activity: The animals were randomly divided into five groups of five rats each and infected intraperitoneally with $T$. brucei brucei $\left(1 \times 10^{5}\right)$. The hydroethanolic extract was administered by galvage to Groups II, II and IV at daily doses of 100, 200 and 400 $\mathrm{mg} / \mathrm{kg}$ body weight respectively for 6 days. Groups I and $\mathrm{V}$ received distilled water (vehicle) and $3.5 \mathrm{mg} / \mathrm{kg}$ Diminazene aceturate respectively. Parasitaemia was monitored daily in blood obtained from the tail of the rats. A wet film and haematocrit buffy coat methods (Murray et al., 1983) were used for the initial detection of parasitaemia. The degree of parasitaemia was estimated as previously described (Herbert and Lumsden, 1976). Packed cell volume and other haematological parameters were determined according to the standard method (Schalm et al., 1975). The mean survival periods of the animals were
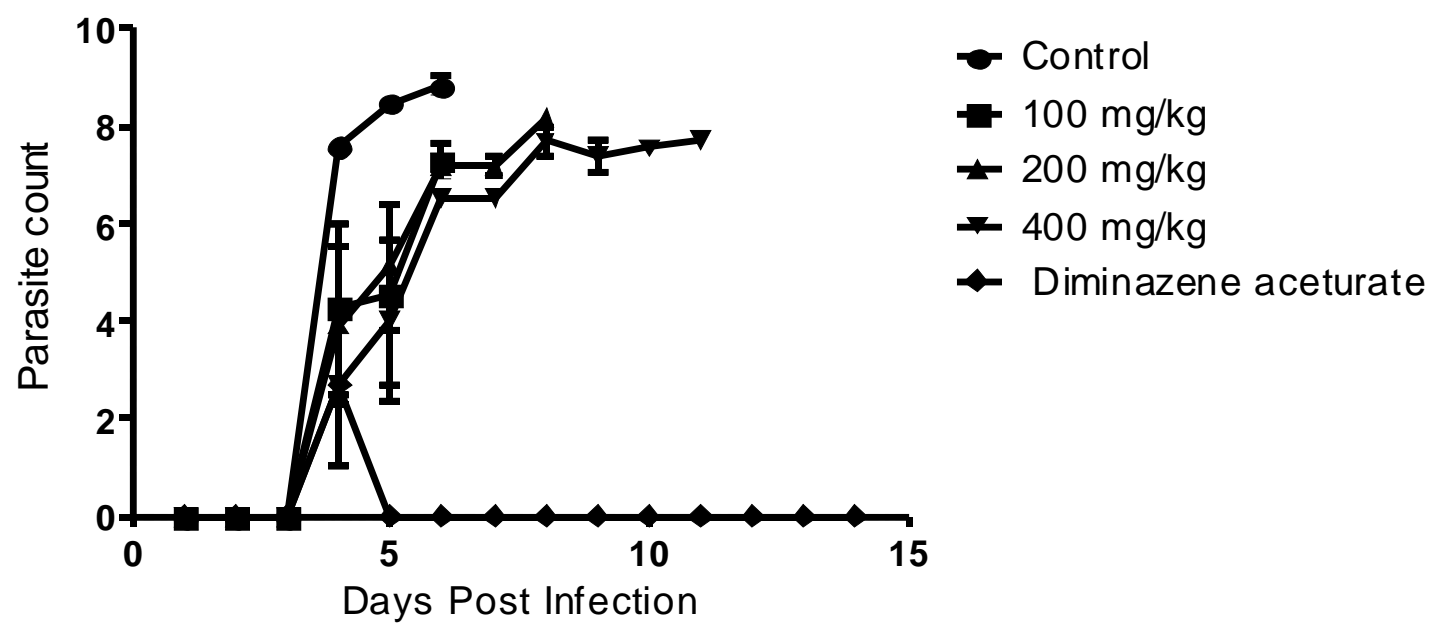

Figure 1: Daily Parasitaemia 
also monitored.

Parasite: Stabilates of T. brucei brucei (federe strain) were obtained from the National Institute for Trypanosomosis Research, Vom, Jos, Nigeria. The parasites were maintained in the laboratory by passage in mice. Blood harvested from a donor animal at peak parasitaemia was used for in vivo trypanocidal assay.

Statistical analysis: The results are expressed as mean \pm standard error of mean (SEM) using Graph Prism statistical package.

\section{Results}

Phytochemical screening of $H$. acida revealed the presence of alkaloids, glycosides, flavonoids, saponins, tannins and terpenoids as shown in Table 1. Anthraquinones and phlobatannins were not detected in the extract.

In vivo trypanocidal activity- The parasitaemia of infected, untreated and infected but treated groups are as shown in Figure 1. In all the groups, parasites were first sighted 4 or 5 days post infection. In Group 1 (infected, untreated), there were progressive increases in parasitaemia until the rats died 5 to 6 days post infection (0\% survival). Results showed that parasites in the blood stream of rats treated with Diminazene aceturate (positive control) were completely eliminated on day 5 . The rats remained aparasitaemic and survived beyond the 14 - day observation period (100\% survival). The extract did not affect the onset of parasitaemia, but was able to reduce its level and prolong the lifespan of the treated rats. Oral administration of the extract did not significantly $(P>0.05)$ affect the packed cell volume. The initial increases in total leukocyte counts were followed by decreases towards the terminal stage of the infection. There were no marked differences in lymphocyte, neutrophil, monocyte and eosinophil counts respectively.

\section{Discussion}

The prepatent period of 4 to 5 days observed in the present study is consistent with earlier findings (Umar et al., 2007). These investigators reported that an acute infection associated with sudden death and rapid rise in parasitaemia is a feature of this strain of trypanosome. Trypanosomes have the capacity to divide very rapidly resulting in their large population in the blood stream of host animal within short time.

The hydroethanolic extract of Hymenocardia acida stem bark did not completely eliminate the parasites from the blood stream of infected rats, but only reduced the level of parasitaemia. Several researchers made similar observations on reduction in parasitaemia and concluded that high parasite load could mask the efficacy of crude extract (Ekanem et al., 2008). Efficacy of crude extracts might also require administration via parenteral route or in exceedingly high doses which sometimes causes toxicity and mortality. In a pilot study, administration of the extract at $20 \mathrm{mg} / \mathrm{kg}$ body weight intraperitoneally (i.p) had no effect on the parasites. But at higher doses i.p. the rats died within 24 hours of administration of the extract. Also the reduced efficacy of crude extract of $\mathrm{H}$. acida could be due to enzymatic inactivation of active compounds or impaired absorption from the gut or both (Mann et al., 2009). Many natural products exhibit trypanocidal efficacy by generating free radicals which interfere with the redox balance of the parasite (Atawodi et al., 2003) or by binding on kinetoplast DNA of the trypanosomes (Nok et al.,1993). Trypanosome generated reactive oxygen species can also attack red blood cells' membranes, induce oxidation and subsequently hemolysis (Karori et al., 2008). Thus, scavenging the trypanosome associated free radicals may ameliorate anemia. Anemia assessed by a drop in packed cell volume is a consistent feature of trypanosomosis.

The near stable packed cell volume of rats given $H$. acida extract orally is suggestive of its potential to ameliorate anaemia (Mpiana et al., 2007). The free radical scavenging activity of $H$. acida is well established (Sofidiya et al., 2006). Leucocytosis due to lymphocytosis observed at the outset and leucopenia at the terminal stage of the infection is a phenomenon associated with waves of parasitaemia (Losos and Ikede, 1972) and the wax and wear syndrome on the host's immune system (Anosa, 1988). Hymenocardia acida stem bark extract did not induce leucocytosis, but extended the life span of rats in the treatment groups compared with the negative control group. The prolongation of life span in infected groups following oral administration of the crude extract agrees with previous reports (Asuzu and Chineme, 1990; Abubakar et al., 2005). Some of the infected rats which were treated with the extract still died even when they had low parasitaemia. Death of rats at low parasitaemia was attributed to the release of extra cellular factors other than the direct effects of the parasites.

The trypanocidal property of the extract might be due to the action of one or more constituents. The present study did not involve detailed characterization and isolation of different compounds that could be responsible for the observed activity. However, s, 
phytochemical screening revealed the presence of saponins, tannins, flavonoids, terpenoids and alkaloids (Table 1). Several scientists have either identified or isolated tannins or phenolic compounds (Shuaibu et al., 2008; Kubata et al., 2005), flavonoids (Ambrozin et al., 2004) and alkaloids (MerschJohann et al., 2001) in plants that showed trypanocidal activities. Bioassay guided isolation of active compounds might enhance the efficacy of the extract. This study demonstrated the antitrypanosomal potential of $H$. acida (stem bark) which could further be exploited in the management of African trypanosomosis.

\section{Acknowledgement}

Authors gratefully acknowledge the technical assistance of Mr Daniel Achanya of Department of Veterinary Physiology, Pharmacology and Biochemistry, University of Agriculture, Makurdi.

\section{References}

1. Abu, A.H., Ofukwu, R.A and Mazawaje, D. (2009). A study of traditional animal health care in Nasarawa state, Nigeria. American-Eurasian J. Sust. Agric. 3 (3), 468 - 472.

2. Abu, A.H., Uchendu, C.N. and Ofukwu, R.A. (2009). In vitro antitrypanosomal activity of crude extracts of some Nigerian medicinal plants. J. App. Biosci., 21: 1277-1282.

3. Abubakar, A., et.al.(2005). Antitrypanosomal and haematological effects of selected Nigerian medicinal plants in Wistar rats. Biokemistri. 17 (2): $95-99$.

4. Akpavie, S.O., Ikede, B.O. and Egbunike, G.N. (1987) Ejaculate characteristics of sheep infected with Trypanosoma brucei and Trypanosoma vivax changes caused by treatment with diminazene aceturate. Res. Vet. Sci., 42(1):1-6.

5. Amaechi, N. (2001). Toxicity of antiprotozoan drug, diminazene aceturate in rats. J. Sust. Agric. Environ., 3(2): 365-370

6. Ambrozin, A.R.P., Vieira; P.C., Fernandes, J.B., Fernandes da Silva, M.F. and de Albuquerque, S.(2004). Trypanocidal activity of Meliaceae and Rutaceae plant extracts. Mem. Do Inst. Oswaldo Cruz., 99: 2: 227-231.

7. Anosa, V.O. (1988). Haematological and biochemical changes in human and animal trypanosomosis. Rev. d' Elev. et de Med. Vet. des Pays Trop., 41: 151-164.

8. Atawodi, S.E., et.al. (2002). Indigenous knowledge system for treatment of trypanosomosis in Kaduna state of Nigeria. J. Ethnopharmacol., 79 (2): 279-282.

9. Atawodi, S.E., et. al. (2003). In vitro trypanocidal effects of methanolic extracts of some Nigerian savannah plants. Afr. J. Biotechnol., 2(9): 317-321.

10. Atindehou, K.K., et. al.(2004). Antitrypanosomal and antiplasmodial activity of medicinal plants from Cote d'Ivoire. J. Ethnopharmacol., 90: 221 - 227.

11. Asuzu, I.U. and Chineme, C.N.(1990). Effects of Morinda lucida leaf extract of Trypanosoma brucei brucei infection in mice. J. Ethnopharmacol., 30:307-313.

12. Ekanem, J.T., Kolawole, O.M. and Abbah, O.C. (2008). Some biochemical and haematological effects of black seed (Nigella sativa) oil on Trypanosoma brucei infected rats. Afr. J. Biochem. Res., 2(2): 45 - 50.
13. Faye, D., et. al. (2004). Effects of an experimental T. congolense infection on the reproductive performance of WestAfrican Dwarf goats. Theriogenol. 62(8): 1438-1451.

14. Herbert, W.J. and Lumsden, W.H.R. (1976). Trypanosoma brucei: a rapid "matching method" for estimating the host's parasitaemia. Exp. Parasitol., 40: 427 - 431.

15. Hoet, S.,et.al. (2004). In vitro antitrypanosomal activity of ethno-pharmacologically selected Beninese plants. $J$ Ethnopharmacol., 91:37-42.

16. Ibrahim, M.A., Njoku, G.C. and Sallau, A.B.(2008). In vivo activity of stem barks aqueous extract of Khaya senegalensis. Afr. J. Biotechnol., 7(5): 661 - 663.

17. Karori, S.M., et. al.(2006). Different types of tea products attenuate inflammation induced in Trypanosoma brucei infected mice. Parasitol. Internat. 57: 325 - 333.

18. Kubata, B.K., et. al.(2005). Kola acuminata proanthocyanidins: a class of antitrypanosomal compounds effective against Trypanosoma brucei.Internat. J. Parasitol., 35:91 - 103.

19. Losos, G.J. and Ikede, B.O. (1972). Review of the pathology of domestic and laboratory animals caused by Trypanosoma congolense, Trypanosoma vivax, Trypanosoma brucei, Trypanosoma rhodiense and Trypanosoma gambiense. Vet. Pathol. 91: 1 - 7 .

20. Mann, A., et. al. (2009). Evaluation of in vitro antimycobacterial activity of Nigerian plants used for treatment of respiratory diseases. Afr. J. Biochem. Res., 3(1): 5 - 8

21. Maser, P., Luscher, A. and Kaminsky, R. (2003). Drug transport and drug resistance in African trypanosomes. Drug Resistance Updates 6(5): 281 - 290.

22. MerschJohann, K., Sporer, F., Steverding, D. and Wink, M.(2001). In vitro effect of alkaloid on blood stream forms of Trypanosoma brucei and Trypanosoma congolense. Planta Med., 67(7): 623 - 627.

23. Murray, M., et. al. (1983). Livestock Productivity and Tyrpanotolerance: Network Training Manual. ILCA, Addis Ababa, Ethiopia, 1983, Pp 4-10.

24. Nantulya, W.M. and Moloo, S.K. (1989). Recent developments in trypanosomosis. Internat. J. Anim. Sci., 4: $71-84$.

25. National Institute of Health (N.I.H). Guide for the care and use of laboratory animals. DHEW Publication. Office of Science and Health Reports, Bethesda, U.S.A., 1985.

26. Nok, A.J., et. al. (1993). Trypanocidal potentials of Azadirchta indica: In vivo activity against Trypanosoma brucei brucei of leaf extract. J. Clin. Biochem. Nutr. 15: 113 - 118.

27. Odebiyi, O.O. and Sofowora, E.A. (1978). Phytochemical screening of Nigerian medicinal plants. Lloydia, 41: 234-235.

28. Schalm, O.W., Jain, N.C. and Caroll, E.J. Veterinary Haematology, 3rd Edition, Lea and Lebiger Publishers, Philadelphia, (1975) Pp 207 - 209.

29. Shuaibu, M.N. et. al.(2008). Trypanocidal activity of extracts and compounds from the stem bark of Anogeissus leiocarpus and Terminalia avicennoides. Parasitol. 102(4), $697-703$

30. Sofidiya, M.O., et. al.(2006). Free radical scavenging activity of Nigerian plant extracts. Pak. J. Biol. Sci., 9(8): $1438-1441$

31. Mpiana P. T., Tshibanga D.S.T., Shetonde O.M. and Ngbolua K.N. (2007). In vitro antidrepanocytary activity (antisickle cell anaemia) of some Congolese plants. Phytomedicine 14: $192-195$.

32. Umar, I.A., et. al. (2007). Amelioration of anaemia and organ damage by combined intraperitoneal administration of vitamins $\mathrm{A}$ and $\mathrm{C}$ to Trypanosoma brucei brucei infected rats. Afr. J. Biotechnol., 6(8): 2083 - 2086. 